doi: 10.17492/mudra.v3i2.7895

\title{
Post Amalgamation Prospects of Regional Rural Banks (RRBs) in Odisha: Policies and Practices
}

\author{
Mitali Chinara* and Anshuman Kamila **
}

\begin{abstract}
Regional Rural banks (RRBs) have been players in the regional and rural banking field since 1970s, continuously mobilising small savings from and disbursing credit to primary livelihoods. Despite certain key advantages with regard to portfolio of deposits, RRBs have lagged behind vis-à-vis their potential. A legacy of accumulated losses, a ballooning quantum of NPAs, rising incidence of frauds and adverse HR environment continue to be a drag on their prospects. A holistic reform which addresses all these concerns along with infusing a vibrant work culture in RRBs is the need of the hour.
\end{abstract}

Keywords: Regional Rural Banks; Credit; Post amalgamation; Odisha.

\subsection{Introduction}

The nationalisation of banks in 1969 boosted the confidence of the public in the banking system of the country. However, in the early 1970s, there was a feeling that even after nationalisation, there were cultural issues which made it difficult for commercial banks, even under government ownership, to lend to farmers. This issue was taken up by the government and it set up Narasimham Working Group in 1975. On the basis of this committee's recommendations, a Regional Rural Banks Ordinance was promulgated in September 1975, which was replaced by the Regional Rural Banks Act 1976. Consequently, the development process of RRBs started on 2 October, 1975 with the forming of the first RRB, the 'Prathama Grameen Bank'. Further, on 2 October 1976 five RRBs were set up with a total authorised capital of Rs. 100 crore which later augmented to 500 crore.

*Associate Professor, P G Department of Analytical And Applied Economics, Utkal University, Bhubaneswar (email: mitalichinara@yahoo.co.in)

**M.A. (Economics), Department of Economics, Delhi School of Economics, Delhi University, Delhi (email: kamila.anshuman@gmail.com) 
The regional rural bank was owned by the Central Government, the State Government and the Sponsor Bank, which held shares in the ratios of 50\%, 15\% and $35 \%$ respectively. There were five commercial banks, Punjab National Bank, State Bank of India, Syndicate Bank, United Bank of India and United Commercial Bank, which sponsored the regional rural banks. From a modest beginning of 6 RRBs with 17 branches covering 12 districts in December, 1975 the number of RRBs increased to 196 RRBs with 14,446 branches in 1991 operating in 518 districts across the country. RRBs made monumental strides in terms of performance and development indicators substantiated by the fact that their deposits grew by 18 times and advances by 13 times between 1980 and 1990. Between 1990 and 2004, deposits and advances grew by 14 times and 7 times respectively. Between 2000 and 2004, loans disbursed by RRBs more than doubled reflecting efforts by these banks to improve credit flow to rural sector.

\subsection{Performance Review}

Within a year of inception of RRBs, the Committee set up by the Reserve Bank of India in June 1977 (Committee on Rural Banks - Dantwala Committee) to review the working of RRBs came to the conclusion that within a short span of two years, they have demonstrated their capability to serve the purpose for which they were established. Therefore, the program for the establishment of more RRBs deserved to be accelerated. The Committee conducted a study on the viability of regional rural banks. It revealed that it was not possible for all branches to become viable because some branches were located at centers where the potential had been limited. Some branches could not expand their business because of keen competition from branches of commercial and cooperative banks. In recognising that the qualitative and quantitative dimensions of the credit gap are so large that neither the commercial banks nor cooperative would be able to fill those up it conceded that RRBs are needed to make good some of the inadequacies in the existing rural credit system and they should become an integral part of rural credit structure. With an eye on increasing the profitability and viability of RRBs, it suggested that commercial banks functioning in the area of operation of RRBs should progressively entrust the credit business of their rural branches to RRBs keeping in view the capacity of RRBs to shoulder the added responsibility. In addition, a plethora of recommendations (Annexure I) were submitted with combined objectives of improving commercial viability and diversifying their business mix, emphasising the original objectives of the RRBs, bolstering the managerial capability of RRBs and upgrading the skill set of staff. 
Since the political environment of the times were pro-poor and scant regard was paid to commercial viability and future prospects of RRBs, the same figured prominently as the overarching theme of approach towards RRBs. For instance, the committee to review arrangements for institutional credit for agriculture and rural development (CRAFICARD, 1981) examined the role of RRBs in the rural credit system and recommended that, as RRBs were more suitable for rural development work, preference should be given to them in regard to licensing of branches in the rural areas. The committee also recommended that such banks should continue to confine their operations to the weaker sections. Allied recommendations (Annexure I) were a mix of subsidisation of RRBs by the gap filling measure of offsetting losses by shareholders and allowing nominal diversification of business mix by RRBs in areas where pure-pro-poor focus would be severely unviable.

In a first indication of shifting sands in policy pertaining to RRBs - in the direction of making RRBs economically viable and self-sustaining financial institutions the Working Group on Regional Rural Banks (Kelkar Committee, 1984) reported back on improving the viability, efficiency and managerial effectiveness of RRBs. Its broad recommendations (Annexure I) suggested that RRBs be allowed to lend to institutions of sound financial character with pronounced investment in productive activities, merger of sick RRBs and changing investment portfolio of RRBs to allow them to invest in government securities (SLR). The report was largely ignored, even as RRBs continued to deteriorate in balancing their assets and liabilities.

In a most detailed assessment of the lacunae and ailing aspects of RRBs, the Agricultural Credit Review Committee (ACRC, 1989) headed by Prof A M Khusro highlighted the operational deficiencies (Annexure I) in RRBs' functioning and acknowledged that non-viability was built into the structure of RRBs. Insightfully, it recommended that the only feasible alternative would be to merge the RRB-structure and the branches with the concerned sponsor banks by making necessary amendments to the existing laws. This, however, was again ignored by the Government. Subsequently, the Narasimhan Committee (1991) on 'Financial Sector Reforms' urged setting up of rural banking intermediaries and mergers on an urgent and emergent basis.

\subsection{Role of Reforms}

The Narasimhan Committee recommendations were taken up and implemented in earnest. Starting 1993, reforms in the sector of RRBs have taken place in three phases: 
72 | MUDRA: Journal of Finance and Accounting, Volume 3, Issue 2

A. First Phase (1993-2000): Reforms were initiated in 1993 with a view to improve the financial health and operational viability of RRBs. Various measures including recapitalisation, rationalisation of branch network, providing better access to nonfund business, expanding avenues of investment and advances, upgrading the level of technology and taking up select RRBs for comprehensive restructuring were undertaken. Further, they were permitted to lend to non-target group borrowers up to 60 per cent of new loans. From January, 1995 the investment avenues for RRBs were broadened to improve the operational efficiency and profitability. In December, 1996 the investment policy was further liberalised, to accord parity with commercial banks, permitting RRBs to invest in shares and debentures of corporate and units of Mutual Funds with a ceiling upto 5\% of the incremental deposits of the bank during the previous year. Prudential accounting norms of income recognition, asset classification, provisioning and exposure, were implemented during this period to provide durability to the reform process. In April, 2000, RRBs were allowed to apply for permission to maintain non-resident accounts in rupees. Such reforms were underpinned by recommendations of multiple committees, working groups and expert groups which were constituted from time to time to consider aspects and suggest ways to improve business viability of RRBs enhance their autonomy, spruce up their investment options and boost the morale and proficiency of their staff (Annexure I).

B. Second Phase (2004-2010): The next phase of reforms started in 2004-05 with the structural consolidation of RRBs by amalgamation of RRBs of the same sponsor bank within a State. This was based on the recommendations of two-plank merger of RRBs, flowing from Advisory Committee on Flow of Credit to Agriculture and Related Activities (Dr Vyas Committee 2004.) Capital support aggregating Rs. 1796 crore was provided during the period 2007-08 to 2009-10 as part of this process. In October, 2004, RRBs were permitted to undertake insurance business without risk participation and in May, 2007 they were allowed to take up corporate agency business for distribution of all types of insurance products without risk participation. In December, 2005, to further extend support to RRBs for accelerating the flow of credit to the rural areas, the resource base of RRBs was expanded to include lines of credit from sponsor banks; they were also permitted to access the term money markets and CBLO/Repo markets. Issuance of credit/debit cards, setting up of ATMs, opening of currency chests, undertaking government business, as subagents, were allowed to enhance business opportunities. In March 2006, RRBs were permitted to apply for AD-Category II licence to undertake non-trade related current account transactions for certain specified purposes to further enhance the scope of 
business. In June 2007, to increase their exposure to foreign exchange business they were allowed to accept FCNR deposits. RRBs were also allowed to participate in consortium lending with sponsor banks, DFIs and other banks within the area of operation. The capital adequacy standards were introduced in December 2007 in the context of financial stability and RRBs were required to disclose the level of CRAR in their balance sheets. Such proactive measures which included coalescence of RRBs and augmenting their business opportunities to include them in profitable and high returns financial services have had significant impact on their fiscal soundness. In the discussion to follow, secular trend in increasing profit margins is discernible.

C. Third Phase (2010 onwards): Based on the recommendations of Dr. K. Chakrabarty Committee (2011) (Annexure I), 40 out of 82 RRBs have been taken up for recapitalisation to enable them to achieve and sustain a CRAR of 9\% from 31 March 2012; the remaining RRBs were found to achieve the requisite CRAR by the said date on their own and sustain the same thereafter. Additionally, the facility of recapitalisation was made available subject to signing of a result-target-framework agreement on pre-specified performance standards. The Regional Rural Banks (Amendment) Act 2014 provides for raising the ceiling on authorised capital of RRBs from existing Rs 5 crore to Rs 2000 crore, over and above the recommendations of the Chakrabarty Committee. In November, 2010 the branch licensing policy was liberalized which allowed RRBs to open branches in Tier 3 to Tier 6 centres (with population of up to 49,999 as per 2001 Census) without prior approval from the Reserve Bank, subject to certain conditions. This policy was further liberalised in August, 2013 to also include Tier 2 centres. The second phase of consolidation commenced from October, 2012 with amalgamation of RRBs across sponsor banks within a State. At the end of such consolidation, only a single RRB shall function per state with jurisdiction extending over all districts.

The Regional Rural Banks (Amendment) Act 2014 passed by Indian Parliament on April 28, 2015 is the latest policy document on RRBs in India. The act envisages further strengthening of RRBs by reinforcing their authorised capital and provides for enlarging the scope of funds to be accessed by RRBs. The focus is on introducing, in a phase-wise manner, greater standards of corporate governance and granting greater operational autonomy. Concerted efforts are also planned to attract the best talent for managerial positions of RRBs and bringing in reforms as regards tenure and job-linked-incentives are concerned. Participative management and decision making by shareholders is also provided for. (Annexure II) 
74 | MUDRA: Journal of Finance and Accounting, Volume 3, Issue 2

\subsection{Post Amalgamation Performance}

Performance of RRBs post amalgamation has been largely satisfactory as it shows signs of improving profit margins and decline in number of loss making entities. A cursory glance at the statistics reveals such distinctly secular pattern (Table 1).

Table 1: Performance of RRBs: 2005-6 to 2013-14

\begin{tabular}{|l|l|l|l|l|l|l|l|l|l|}
\hline & $\begin{array}{c}2005- \\
06\end{array}$ & $\begin{array}{c}2006- \\
07\end{array}$ & $\begin{array}{c}2007- \\
08\end{array}$ & $\begin{array}{c}2008- \\
09\end{array}$ & $\begin{array}{c}2009- \\
10\end{array}$ & $\begin{array}{c}2010- \\
11\end{array}$ & $\begin{array}{c}2011- \\
12\end{array}$ & $\begin{array}{c}2012- \\
13\end{array}$ & $\begin{array}{c}2013- \\
14\end{array}$ \\
\hline No of RRBs & 133 & 96 & 90 & 86 & 82 & 82 & 82 & 64 & $57^{1}$ \\
\hline No of branches & 14489 & 14563 & 14790 & 15524 & 15475 & 16024 & 16914 & 17867 & $17588^{2}$ \\
\hline $\begin{array}{l}\text { Net profit (Cr of } \\
\text { Rs) }\end{array}$ & 617 & 625 & 1027 & 1335 & 1884 & 1785 & 1886 & 2384 & $2744^{1}$ \\
\hline $\begin{array}{l}\text { Profit/Loss } \\
\text { making RRBs }\end{array}$ & $111 / 22$ & $81 / 15$ & $82 / 8$ & $80 / 6$ & $79 / 3$ & $75 / 7$ & $79 / 3$ & $63 / 1$ & $57 / 0$ \\
\hline $\begin{array}{l}\text { Deposits(Cr of } \\
\text { Rs) }\end{array}$ & 71329 & 83144 & 99093 & 120189 & 145035 & 166232 & 186336 & 211457 & $239511^{2}$ \\
\hline $\begin{array}{l}\text { Loans+Advances } \\
\text { (Cr of Rs) }\end{array}$ & 38520 & 47326 & 57568 & 65609 & 79157 & 94715 & 113035 & 133098 & 218110 \\
\hline CD ratio (\%) & 55.7 & 58.3 & 59.5 & 56.4 & 57.6 & 59.51 & 63.3 & 66.13 & $67.49^{3}$ \\
\hline $\begin{array}{l}\text { Share of CASA } \\
\text { in deposits (\%) }\end{array}$ & 59.14 & 61.21 & 59.63 & 58.35 & 57.9 & 60.35 & 58.51 & 57 & $54.3^{4}$ \\
\hline $\begin{array}{l}\text { Share of PSA in } \\
\text { total (\%) }\end{array}$ & 81 & 82.2 & 82.9 & 83.4 & 82.2 & 83.5 & 80 & 86 & \\
\hline $\begin{array}{l}\text { Share of agri adv } \\
\text { in total (\%) }\end{array}$ & 54.2 & 56.6 & 56.3 & 55.1 & 54.8 & 55.7 & 53 & 63 & \\
\hline Gross NPA (\%) & 7.3 & 6.55 & 6.1 & 4.2 & 3.72 & 3.75 & 5.03 & 5.65 & $6.08^{5}$ \\
\hline Net NPA (\%) & & 3.46 & 3.36 & 1.81 & 1.62 & 2.05 & 2.98 & 3.40 & $4.35^{2}$ \\
\hline
\end{tabular}

Source: Reports on Trends and Progress of Banking in India \& NABARD, allied sources

Notes: 1. From www.allbankingsolutions.com/Banking.../Regional-Rural-Banks-RRBs.pdf

2. From http://banks-india.com/banking-news/list-of-regional-rural-banks-rrbs-in-india/

3. From indiastat.com

4. From http://articles.economictimes.indiatimes.com/2014-03-03/news/47859454_1_sponsor-banks-rrbs-casa

5. From http://articles.economictimes.indiatimes.com/2014-02-25/news/47670864_1_rrbs-regional-rural-bankssenior-nabard-official 
As is clear from the statistics above (Table 1), alongside a decrease in absolute numbers of RRBs, there has been an expansion in number of branches, through which existing RRBs offer their services to the populace. No of loss making units as a proportion of total number of RRBs has fallen, barring mild fluctuations in the interim period. Priority sector continues to command substantial chunk of loans and advances, a trend shared by agriculture. However, a worrying trend is the rise in NPAs which blot the portfolio of RRBs.

\subsection{RRBs in Odisha}

Odisha had 12 RRBs to begin with, which in 2012-13 were amalgamated across the Sponsor Banks to form 5 RRBs by September 2013. The details are given in Table 2. In the subsequent round of amalgamation, 2 major RRBs were created by further mergers. These are: (i) Utkal Grameen Bank (UGB) - headquartered in Bolangir, Odisha -sponsor bank State Bank of India; and (ii) Odisha Gramya Bank(OGB) - headquartered in Bhubaneswar, Odisha - sponsor bank, Indian Overseas Bank

Table 2: RRBs in Odisha

\begin{tabular}{|c|c|c|}
\hline Sponsor Bank & Amalgamated RRB & Constituent RRB \\
\hline \multirow[t]{2}{*}{ Indian Overseas Bank } & \multirow[t]{2}{*}{ Neelachal Gramya Bank } & Puri GB \\
\hline & & Dhenkanal GB \\
\hline \multirow[t]{2}{*}{ UCO Bank } & \multirow[t]{2}{*}{ Kalinga Gramya Bank } & Balasore GB \\
\hline & & Cuttack GB \\
\hline \multirow[t]{3}{*}{ State Bank of India } & \multirow[t]{3}{*}{ Utkal Gramya Bank } & Bolangir Anchalik GB \\
\hline & & Kalahandi Anchalik GB \\
\hline & & Koraput Panchabati GB \\
\hline State Bank of India & \multirow[t]{2}{*}{ Utkal GB } & Utkal Gramya Bank \\
\hline Andhra Bank & & Rushikulaya GB \\
\hline Indian Overseas Bank & \multirow[t]{3}{*}{ Odisha Gramya Bank } & Baitarani GB \\
\hline Bank of India & & Kalinga GB \\
\hline UCO Bank & & Neelachal GB \\
\hline
\end{tabular}

Source: indiastat.com

With respect to the jurisdiction of the respective RRBs, UGB operates in 17 districts of Western and Southern Odisha - Bolangir, Sonepur, Bargarh, Sambalpur, Deogarh, Jharsuguda, Sundargarh, Kalahandi, Nuapada, Kandhamal, Boudh, Ganjam, 
Gajapati, Koraput, Malkangiri, Rayagada and Nabarangpur - covering 63\% of geographical area and $48 \%$ of total population of the state. As for OGB, it serves the populace in the remaining 13 districts, concentrated primarily in the Eastern and Coastal regions - Mayurbhanj, Balasore, Bhadrak, Keonjhar, Jajpur, Kendrapara, Dhenkanal, Angul, Nayagarh, Khurdha, Puri, Jagatsinghpur and Cuttack - catering to over 37\% of geographical area and $52 \%$ of total population of Odisha.

Subsequent to budgetary pronouncements involving roles and responsibilities of RRBs in 2004-05, it was decided by the RBI to provide an institutionalised mechanism to resolve all operational and regulatory problems of RRBs at the earliest which will enable the RRBs to adopt good governance and comply with prudential regulations and play their assigned role effectively. Thus, Empowered Committees (ECs) of RRBs were constituted in September 2004 at all regional offices of the RBI.

The EC on RRB comprises of the Regional Director of RBI as Chairman and Officer-In-Charge of Regional Office of NABARD, a senior official each from the sponsor banks (usually the Chief General Manager), a senior officer from the convenor bank of SLBC and a senior officer from the State Government (usually the Director of Institutional Finance, as in Odisha) as members. The Chairmen of RRBs were subsequently inducted to share their experience and enable them to present their individual cases and specific problems. In Sadakadulla (2007), ECs have been hailed as harbinger of prosperity of RRBs, since long standing issues of RRBs - including those with their sponsor banks - could be expeditiously resolved, branch licensing could be effectively and professionally managed, computerization of RRBs were fast-tracked, inter alia. In Odisha, EC meetings have been crucial forums for detailed deliberations on the financial sustainability of RRBs.

In particular, emphasis has been placed on:

- mounting accumulated losses of RRBs in Odisha; (Table 3)

- high levels of NPAs across RRBs, specifically after integration of CBS platform; (Table 4)

- lack of internal control systems in RRBs;

- sub-optimal business growth rates achieved by RRBs;

- submission of road map to wipe out accumulated losses of RRBs by their management;

- non-participation of RRBs in designated financial inclusion schemes floated by Government of India; and

- augmenting momentum in implementing KCC and SHG linkages of RRBs. 
Table 3: Accumulated losses in Rs crores

\begin{tabular}{|l|l|l|l|}
\hline RRB & As on 31 Mar 2014 & As on 31 Mar 2015 & Y-o-y rise in \% \\
\hline OGB & 325.20 & 428.21 & 31.67 \\
\hline UGB & 69.50 & 128.10 & 84.32 \\
\hline
\end{tabular}

Source: Reports on Trends and Progress of Banking in India \& NABARD, allied sources.

Table 4: Gross NPA in Rs crores

\begin{tabular}{|c|c|c|c|}
\hline \multicolumn{1}{|l|}{ RRB } & As on 31 Mar 2014 & As on 31 Mar 2015 & Y-o-y rise in \% \\
\hline UGB & $393.91(14.32 \%)$ & $725.97(26.14 \%)$ & 84.29 \\
\hline OGB & $463.31(11.63 \%)$ & $1262.13(29.28 \%)$ & 172.41 \\
\hline
\end{tabular}

Source: Reports on Trends and Progress of Banking in India \& NABARD, allied sources.

\subsection{Findings of the Study}

In order to gain a first-hand experience in the administration and operations in a RRB, field visits to the Head Offices of Odisha Gramya Bank and Utkal Grameen Bank were organised. A consolidated statement of findings and perceptions is as follows:

a) Diversification of lending profile to enhance earnings from advances: Although the initial focus of the RRB was on traditional agricultural loans, particularly crop loan (which continues to comprise $25 \%$ of the lending portfolio), the bank has been diversifying its lending to include MSMEs, housing loans, educational loans, clean loans to salaried individuals, demand loans against NSCs, KVPs, LIC policies and other corporate loans. With such dynamism in lending activities, the RRBs have bridged the gap between a conventional RRB and a scheduled commercial bank. Despite the fact that it is mandatory for RRBs to maintain 60\% of their advances (as against $40 \%$ or less requirement for SCBs) as PSL, two things to be noted are - i) PSL category has come to include a wide plethora of activities such as educational loans, MSME loans, etc. which offer secure and higher returns than a restricted PSL category as before; ii) government schemes and NABARD programs offer interest subvention on PSL activities, which increase the gross return from such advances. Increasingly, the gap between PSL and non-PSL assets in terms of returns/income has been bridged.

b) Investment of non-SLR surplus funds: The RRB has endeavoured to maintain a high credit-deposit ratio and invests the surplus funds thereof in safe and secure assets such as SLRs and fixed deposits. As far as fixed deposits are concerned, RRBs have 
proactively parked their non-SLR investments across PSBs - like Punjab and Sind Bank, UCO Bank, IDBI Bank - apart from their sponsor bank, on a competitive basis. The choice of investment avenue is guided strictly by consideration of higher interest rate offered by a PSB on the said date. No bias towards or against sponsor bank, beyond purely pecuniary calculation, reportedly exist.

c) Increasing business mix/profile: Staff and human resource constraints impede fullfledged adoption of para-banking activities by the RRB. Although an MoU had been signed between the RRB and Universal Sompo General Insurance Company, retailing of their product was not being done in a spirited manner - because i) the bank does not earn commensurate compensation to offset costs incurred at PoS (HR costs, time costs, stationery, etc) ii) no incentive structure has been devised for bank staff who are tasked with retailing these products. The top brass feels that focusing on retailing of LIC products under the GoI's Jan Dhan Yojana and/or products of Universal Sompo, under the current compensation structure is unprofitable for the bank monetarily as also will divert attention of staff members from more pressing concerns of the bank, such as monitoring follow up and resolution of NPAs. However, the overall consensus seemed to be in the direction that diversification of business mix to include retailing adequately compensating insurance products, inter alia, is essential for long term sustainability and business profitability of the bank.

d) Increasing competition with PSBs and private sector banks opening branches in rural areas: The RRB has acknowledged the strategy of PSBs and private banks making inroads into the rural banking sector. Having conventionally enjoyed more pervasive presence in the rural banking scenario, RRBs are now being allotted targets to set up branches - in brick and mortar (BM) and banking correspondent (BC) models - in unbanked villages under the Gol's Financial Inclusion Plans. However on account on staff and fiscal constraints, RRBs have now urged the Ministry of Finance to review and downsize their targets for spread of branches. The management is of the view that by virtue of their long-standing relationships with the rural populace, they'll be preferred over new entrants in the arena - but adequate attention must be paid to keeping up the unblemished people-friendly image of the RRBs, resolving frauds and maintaining sanctity of deposits parked with RRBs.

e) Infrastructure/Amenities available at branches of the RRB: Cognisant of the fact that existing facilities at most branches of the RRB are inadequate and surplus available to invest in upgrading branch infrastructure is also limited, the bank has taken up refurbishing branch amenities at $10 \%$ of branches per year. With initial focus on ensuring basic facilities (chilled drinking water, toilet, ergonomic seating for customers, etc.) the bank also plans to tackle the problem of poor quality of 
accommodation that branches have to contend with in rural areas. While some branches under a particular erstwhile component RRB (Neelachal Gramya Bank) have comparatively better standards of infrastructure, efforts are underway to gradually improve the ambience across branches and a policy has been put in place for the purpose.

f) Industrial relations between management of RRB and employee unions: There has an absence of a unified employees' union post amalgamation - an application for recognition of a unified forum for employees has been submitted and is under consideration of the management for due recognition. While the overall relationship is harmonious, certain sticky issues remain outstanding - such as, the absence of medical cover, discrepancies regarding entitlement for TA, halting allowance, pensions, LFC and leave encashment. There is a legacy of pending litigations and legal hassles which continue to be a baggage for RRBs.

g) Fraud policy and management of pending fraud cases: For prevention of further frauds, which as the management believes is a major image-spoiler for the bank, the management has undertaken measures to implement preventive vigilance, trained vigilance officials on adept handling of investigation, etc. Furthermore, disciplinary proceedings against erring officials in pending fraud cases are being pursued in an expeditious manner. The management is also mindful of the NABARD circular which provides for categorised handling of fraud cases based on the magnitude of the economic offence.

h) NPA management: NPAs have dramatically increased for RRBs after adoption of CBS platform which points out NPAs much more efficiently and swiftly than the manual method adopted heretofore. While NPAs have come to afflict the banking system in India on the whole, RRBs have taken timely notice of the phenomenon of rising NPAs and endeavoured to reduce their levels from current position. Regional Managers have been pressured to invoke SARFAESI act to resolve NPAs wherever willful default is being noticed and to prepare claims under CGTMSE in case of lending to eligible business ventures. Separately, recovery camps are being conducted, Lok Adalats and DRT are being moved, and OTS and OCS schemes are being pushed for non-wilful defaulters. The bank has adopted a proactive stance as regards NPA resolution is concerned - allocating targets, monitoring progress and enforcing adherence to guidelines at branch levels. Regular notices are being sent and other allied mechanisms are being strengthened for better NPA management.

i) Human Resource Policy: The Bank follows a transfer policy which provides for a 3year term for a branch manager and 5-year term for clerical staff - following which, however, postings are made as per circumstantial considerations without an 
established policy (for example, Kendriya Vidyalaya Sangathan, Central Reserve Police Force etc provide for a posting policy which incentivizes postings in 'hard' areas by 'choice' postings following a stint in hard places). Thus there is no certainty for an employee going to a posting against their wish to get a posting of his choice after the current tenure. Second, the transfer-posting policy doesn't promote widescale mobility of staff across the area of operation of the bank, to quell possible resentment and resistance to large scale transfers. For the reasons that several of the serving staff members initially took up employment in RRBs with the tacit assumption that their job would involve fewer and less-inconveniencing transfers and that about $60-70 \%$ of the staff are on the verge of retirement, such a policy to promote wider scale transfers is not advisable either. The management, however, feels that the 'young blood' will accede to transfers if adequately incentivised. Third, performance-linked incentives for staff are very limited under the existing arrangement. There is no stipulation for lucrative bonuses on meeting business targets, except for minimal regional awards (on indicators such as deposits, advances, profits and NPAs) and salary-increments based on JAIIB and CAIIB. This creates a lack of incentives problem for employees of the RRB. Allied to this, the promotion policy for officers in RRBs is also not comparable with the extant avenues in SCBs. For example, it takes a Scale I officer 3 years to make it to Scale II in a SCB, as opposed to 7 years in an RRB; a clerical grade officer takes over 10 years to make the cut for Officer grade in an RRB, much in excess for counterparts in SCBs. Fourth, avenues for upgrading skills of employees of RRBs are very few in number. Apart from facilities for in-house training of employees, the bank sends officers for training to Banker Institute of Rural Development (Lucknow, Bolepur, and Mangalore), National Institute of Bank Management (Pune), Indian Institute of Bank Management (Guwahati), Staff Training College of Indian Overseas Bank (Chennai), College of Agricultural Banking (Pune), etc. However, such opportunities are provided on a need-based criterion, on a limited scale and only when the costs are partially offset by a sponsoring organization (Sponsor Bank/NABARD/GoI). Fifth; current scope for direct recruits of RRBs to make it to the top brass of management, such as officers in the rank of General Manager (GM), Chief General Manager and Chairman is non-existent. However, the recommendations of the Mitra Committee on HR issues of RRBs carve space for direct recruits to rise to the rank of GM; although the same has not been implemented in letter and spirit. The Mitra Committee justifiably recommends progressively curbing the number of offices occupied by officials on deputation from Sponsor Bank to RRBs, to consequently fast-track the promotion of direct recruits of RRBs. Separately, there is no flow of 
personnel from RRBs to their Sponsor Banks - as an award or incentive package. This, despite the fact that highly qualified graduates (including B Tech degree holders) have been inducted into RRBs.

j) Miscellaneous: The management feels that RRBs are being stifled with a multilayered regulation structure - with RBI, NABARD, State Government, Ministry of Finance and Sponsor Bank exerting control over the affairs of the RRB, with very little operational autonomy available. Even as RRBs handle businesses and operations of levels of complexity at par with SCBs, remuneration and salary package in RRBs is quite at variance with that of SCBs. RRBs have increasingly been facing high attrition rates with regard to new recruits and this has made a significant dent on their operational efficiency and hence there's a need to provide for measures to help retain competent recruits in the bank. Inclusion of RRBs in the recently launched financial inclusion drive of the Government of India has obligated them to open no-frill accounts which have imposed costs on RRBs (for instance a bank has to expend Rs 200 to create and maintain records for a no-frills account) which impact their profitability, given the fragility of their existing financial health.

\subsection{Policy Suggestions}

A. NPA Management: Asset quality of banks is one of the most important indicators of their financial health. In this regard it has been observed that NPAs have snowballed as a major issue of concern for the fiscal health of SCBs in India. So much so that the same figured in the Economic Survey of India 2015-16 as a major stress point for the economy under the 'Monetary Management and Financial Intermediation' section. While NPA levels for RRBs as a whole in India have stood at $6.08 \%$ of advances, which for RRBs in Odisha have been a staggering $10.21 \%$, as on May 31 $2014^{2}$. Hidden NPAs have now surfaced on account of migration of the accounting system to a uniform CBS platform which better implements IRAC norms. While RRBs have taken notice of the pressing issue and activated internal mechanisms to fast-track resolution of NPAs, their efforts have to complimented and augmented. It is worthwhile to suggest that:

(i) Sponsor Banks be urged by EC to consider the NPAs of their respective RRBs as seriously as their own and render technical assistance in handling of such NPAs.

(ii) Prudential norms for pre-sanction appraisal of loan proposal, post sanctioning monitoring of credit utilisation and surveillance practices for early detection of potential NPAs must gradually be introduced in RRBs. 
(iii) Capacity building drives for staff of RRBs - including development of appropriate training modules and compilation of case studies - must be accorded a priority and EC will be well posited to oversee the implementation of this proposal in a time-bound manner.

(iv) A scheme for incentivising resolution of NPAs and a package for recognising and felicitating successful branch managers will have to be positively considered by the RRBs in conjunction with their sponsor banks.

B. Business Portfolio Expansion: One of the objectives of nationalization, as that of inception of RRBs, was to ensure adequate credit flow to genuine productive sectors. RBI's credit policy over the years has emphasized on channeling bank credit to preferred sectors and borrowers of small means. Annual targets were laid down for lending to priority sectors as a whole with sub targets for weaker sections of society. This was followed in conjunction with making interest rates market-linked and allowing price discovery mechanism to work, while revoking the regime of 'financial repression', when banking system was subjected to liberalisation. Although RRBs were initially conceived to augment credit flow to low-profit agriculture, small artisans and cottage industries sector, various policy measures have been initiated in recent times to strengthen the finances of RRBs. In September 1992, measures were introduced to allow RRBs to lend to Non-Target Group beneficiaries to the extent of $40 \%$ of fresh advances; subsequently revised to $60 \%$ in January 1994. They were also allowed to engage in lending for non-productive purposes and into non-fund based activities like issuing guarantees, purchase/discount of demand drafts and cheques and to install safe deposit lockers. Furthermore, they're permitted to undertake remittance services and accepting foreign currency deposits with a view to improve their profitability.

In recent times, however, there's a need to further expand their business portfolio to offset the negative impact of rising NPAs and boost revenues for them without locking up funds.

(i) RRBs will have to be encouraged by Sponsor Banks to sign MoUs with insurance and mutual funds companies to undertake grass-roots level retailing of their products. This will turn in neat profits for the RRB without exposing their mobilized funds to risk and uncertainty. Adequate attention must be paid to ensuring that the remuneration and commission structure adopted is rewarding enough for the RRBs.

(ii) RRBs should be proactively involved in acting as conduit for payment of MGNREGA wages, transfer of fertilizer, food and LPG subsidy and other DBT 
schemes of GoI and the state government. After an initial upfront cost of running awareness and enrolment campaigns, the subsequent flow of commission is risk free and perpetual.

(iii) RRBs should be proactively involved in acting as conduit for payment of MGNREGA wages, transfer of fertilizer, food and LPG subsidy and other DBT schemes of GoI and the state government. After an initial upfront cost of running awareness and enrolment campaigns, the subsequent flow of commission is risk free and perpetual.

C. HR Issues: The study highlights several HR-related issues of RRBs. A unified refrain among all officials of RRBs interviewed opined that HR-associated issues are their most pressing challenges, which impact their performance on other fronts such as business diversification, NPA resolution and fraud investigation. It is timely, therefore, to suggest:

(i) Drawing on the recommendations of the study authored by Ernst and Young and the Mitra Committee for HR-related issues of cooperative banks, it is suggested that RRBs evolve sound personnel policy that ensures rational career progression in all categories. A pure seniority based promotion scheme breeds frustration and promotes greater attrition - therefore the call for a more realistic and rational policy for promotion and placement. It is advisable that a two channel promotion model is mooted and operationalised, which encompasses 'Normal channel' based on the concept of Seniority cum Merit and a 'Fast Track' channel based on merit combined with inter-se seniority. The 'Fast Track' channel will be an incentive for performance, to meritorious and good performers. In addition to eligibility, the suitability for promotion may be considered subject to the candidate's service record. (ii) Transfer policy needs to be a composite instrument of combining administrative exigency and the motive of ensuring smooth career progression, while providing exposure to various areas of operations of the bank at different tiers. Current objection to jurisdiction-wide-transfer liability can be tactically dealt with by combining transfers with 'Fast Track' promotions, as elucidated above. The proposed move is along the lines of extant procedures in force in Central government agencies such as the Postal Department, Audit and Accounts Department, etc. Simultaneously, a cogently and comprehensively drafted transfer policy that incentivizes voluntary choice for hard areas needs to be put in place. This will incorporate consistency and predictability in transfers, thereby cultivating more efficient HR management. 
(iii) With the gap between employees of SCBs and RRBs in terms of rigour of jobcontent and impact of market forces closing rapidly, it is imperative that RRB employees are legitimately granted promotional avenues in their organization at par with their counterparts in SCBs. The existing time difference between SCBs and RRBs in elevation of a clerical grade official to the officer grade and upward transition in 'Scale' ought to be eliminated. Instituting this practice shall also help salvage several cases of legal hassles which have historically plagued RRBs in Odisha. It would also be worthwhile to consider a mechanism via which employees, especially in the officers' grade, be offered a scope for deployment in the Sponsor Bank, to learn good practices of banking, to earn exposure to wider scale of allied activities and to imbue the corporate work culture. Such opportunities should be made entirely on the basis of a transparent selection mechanism and on grounds of merit.

(iv) Under the current scheme of staff appointments, a PO recruit of the RRB cannot aspire to climb to the highest echelons of the bank administration. This breeds a culture of despondence and pessimism among serving employees of the RRB, potentially enhancing attrition rates as well. The Mitra Committee recommendations mark a welcome shift, providing for space for original recruits of the bank to become GMs - albeit these have not been implemented in letter and spirit. A long term perspective plan must be devised to progressively enable recruits to reach the peak positions - in line with SCBs.

D. Special Program for revitalising RRBs: RRBs have over time failed to be in sync with evolving standards of banks, with regard to aesthetic appeal of branches, soft skills of front desk managers, corporate work culture and practices for enhanced customer satisfaction. This is borne out in the surveys conducted (Ram and Subudhi, 2014) which point out that customer satisfaction with service quality offered in RRBs is abysmal. This calls for a special mission mode project to be implemented across all RRBs to: (a) Capitalise on the strengths of RRBs, such as broad-based network, historical advantage in enjoying trust of rural and peri-urban populace, etc.; and (b) Recognise and rectify weaknesses, like improve aesthetic appearance of branches, enhance soft skills of staff, build capacity in managing emerging aspects of banking in India, etc.

The key ingredients of the time-bound project must necessarily include:

(i) Identification of key performance indicators (KPI), such as deposits, credit, NPAs etc, involving which targets will be set; 
(ii) Mutual agreement between administration and unions with regard to establishing performance standards and defining targets and aims;

(iii) Continuous appraisal of project implementation by a bipartisan monitoring group, to suggest areas for added emphasis and accelerated thrust;

(iv) Identification of high achievers from among the staff of the bank and award of prizes along with public felicitation;

(v) Creation of a citizen's charter, to enumerate timelines for throughput of services offered at branches of RRBs;

(vi) Imparting operational and soft skills training to staff of RRBs to improve customer relationship management and enhance business-readiness in an atmosphere of increasing competition;

(vii) Regular interface and interaction between the apex of administration and the grass-root level of operations, which induces sense of ownership and responsibility at highest levels and accountability at the lowest levels;

(viii) Drive for change must come from a potent external agency with the courage to accept responsibility for failure and delegate appreciation for success, and which applies performance standards uniformly across all participating RRBs [recognized as the reason why Finance Commission recommendations, however unpalatable, are implemented efficiently and spiritedly ${ }^{3}$.

\subsection{Issues for Further Consideration}

The limited nature of the current study forbids consideration of several other germane issues that need to be considered in relation with RRBs. A few such issues beyond the purview of the current study are:

a) Commencement of operations of emerging banks, such as that floated by Bandhan Financial Services Private Limited, and other such MFIs from semi and peri-urban centres signals a threat to sustenance and expansion in the operations of RRBs. Such MFIs will employ innovative corporate strategies - including personal persuasion, pecuniary incentives, et al - to wean away existing customers of RRBs and capture the under-banked populace. In absence of a rational and potent action plan against maneuvers of these new entrants, RRBs cannot hope to retain their customer base in their captured habitat.

b) RBI has circulated guidelines and accorded in-principle approvals to entities to undertake the business of carrying out the activities of a payment bank. Under the current policy stance, special emphasis is being laid on fostering a conducive atmosphere for inception of more number of payment banks. RRBs will be well 
advised to take notice of such developments and prepare for the inevitable entry of new players in the field, by taking steps to upgrade the bouquet of services currently offered by them and enhancing customer satisfaction with such services.

c) One of the measures employed by GoI in making PSBs market oriented and thereby enhance their targets for performance is to stop repeated budgetary support for recapitalisation. As against exclusive infusion of capital by the government, such banks have been asked to raise capital in the market, in a transparent and competitive manner. Such steps also make it imperative for banks to incorporate high standards of corporate governance and professional management. RRBs will eventually have to plan for a scenario when government support in terms of capital infusion will be negligible, if not non-existent, and it'll be essential for them to raise capital from the market. This calls for elevated levels of performance parameters and a competitive work culture.

d) Shareholding in RRBs, as is common knowledge, is distributed among GoI, State Government and Sponsor Bank in ratio of 50:15:35. However, in the recent past capital infusion has been provided for by one of the stakeholders - the Government of India. This situation is untenable and other stakeholders will also have to provide capital-based support to RRBs in future.

e) It has been noticed that in Board meetings of the RRBs, some prominent members of the Board have not been present during several sessions. Absence of their participation creates a dent in the overall functioning of the RRB, particularly in evaluating whether they are fulfilling the regional objectives and taking key decisions with regard to their policy structure. This does not augur well for participative management of the RRBs, which should be the norm rather than exception.

\subsection{Summative Remarks}

In his book 'The Dramatic Decade: The Indira Gandhi Years', Sh Pranab Mukherjee (President of India, during whose incumbency as Minister of State for Finance, GoI RRBs were initially conceived and constituted) makes a perceptive remark about RRBs - that they were originally conceived to function in a 'low cost-low income' model. Subsequent political churning in India has ruptured the first element of the model - and hence RRBs have to compensate by turning in high incomes. If they fail to evolve under changing dynamics of the banking industry, justifying their independent existence will be difficult. 
Borrowing a few ideas from Jim Collins ${ }^{4}$, the key to success for our RRBs is to confront the 'brutal facts' of their operations, yet be optimistic that a turn-around can be effected by sincere and dedicated efforts. While the HR-related measures proposed require intervention at an elevated level of governance, the revitalization program can well be initiated locally. Much like the Project Arrow of India Post, such a program may well set the stage for a comprehensive transformation of RRBs. Schemes that broaden the business portfolio - such as participation in DBT schemes of the government, retailing of mutual fund and insurance products in rural and semi-urban areas - could be rolled out simultaneously with the revitalization program. Massive capital infusion can be made contingent on attaining a desirable level of business achievements by RRBs. A professional treasury management system could be developed and implemented for increasing efficiency in profitable deployment of CASA deposits.

\section{Endnotes}

1. Regional Rural Banks in India : Past, Present and Future in "Dynamics of Indian Banking: Views and Vistas" by Manoranjan Sharma.

2. From http://www.business-standard.com/article/finance/npas-of-banks-in-odisha-mount-to-769-by-march-114053101476_1.html

3. Taken from "Issues before the Fourteenth Finance Commission" by Dr V Bhaskar, EPW Vol XLVIII No 17, Apr 27, 2013.

4. Jim Collins, the author of Good to Great, Built to Last and How the Mighty Fall, is an American business consultant, author, and lecturer on the subject of company sustainability and growth.

\section{References}

Committee on Regional Rural Banks (Dantwala Committee). (1978). Accessed at shodhganga.inflibnet.ac.in/bitstream/10603/.../09_chapter\%202.pdf

Mathur, Anupam. (2015). Maximising the Post Office. The Hindu, 29 May 2015. Accessed at http://www.thehindu.com/opinion/op-ed/maximising-the-post-office/ article7256701.ece?ref=sliderNews.

Ram, Jitendra Kumar, \& Subudhi, Rabi N. (2014). Customer perception on performance of RRBs in Odisha. Parikalpana-KIIT Journal of Management, 10(I). 
Ram, Jitendra Kumar, \& Subudhi, Rabi N. (2014). Making Regional Rural Banks Market Efficient : A Study on Amalgamation Effect. Presented in ICBPEM.

Ram, Jitendra Kumar, \& Subudhi, Rabi N. (2015). Regional Rural Banks of Odisha : A study on amalgamation impact. GITAM Journal of Management, 13(1), Jan-Mar.

Regional Rural Banks (Amendment) Act. (2014). PRS Legislative Research, India. Accessed at prsindia.org

Sharma, Manoranjan. (2008). Dynamics of Indian Banking: Views and Vistas. Atlantic Publishers and Distributors.

\section{Weblinks}

en.wikipedia.org/wiki/Regional_Rural_Bank

indiapostarrow.gov.in/upload/India-Post-Blue-Book.pdf

odishabank.in

ugb.co.in

www.gktoday.in/reference/regional-rural-banks/

\section{ANNEXURES \\ Annexure I: Major Recommendations of Various Committees / Working Groups/Expert Groups on Regional Rural Banks}

Working Group On Rural Banks (Narasimham Committee, 1975)

- Rural Bank are to be a scheduled commercial bank, to be promoted by GOI, State Government, a commercial bank that may hold equity in proportion of 50:15:25 and other institutions / individuals, might hold balance $10 \%$. Later on, $15 \%$ equity may be open to cooperative banks / societies, other local institutions and individuals so as to foster the spirit of local participation. In exceptional cases, more than one bank may jointly share $25 \%$ equity holding. To encourage local participation, a minimum guaranteed dividend be paid to be $15 \%$ 'other' shareholders.

- Board of Directors to comprise of 09 Directors: 4 by GOI including the Chairman, 2 by sponsor bank, 1 by State Govt., and rest 2 by GOI from amongst remaining 
shareholders.

- Sponsor Bank to provide managerial, financial and training support to the rural bank.

- Chairman to be appointed by GOI in consultation with RBI and sponsor bank with due regard to his professional competence, background and experience.

- Emphasis on viability with recognition that in initial years the rural bank might suffer losses.

- Rural bank to examine the ways of restructuring and reorganizing the productive activities of small borrowers so as to bring them to the level of generating surpluses for the purpose of reinvestment.

- A certain degree of flexibility of operation may be permitted with exemption in existing banking laws and regulations.

Committee on Rural Banks (Dantwala Committee, 1978)

- The qualitative and quantitative dimensions of the credit gap are so large that neither the commercial banks nor cooperative would be able to fill them up. RRBs are needed to made good some of the inadequacies in the existing rural credit system and they should become an integral part of rural credit structure.

- Commercial banks functioning in the area of operation of RRBs should progressively entrust the credit business of their rural branches to RRBs keeping in view the capacity of RRBs to shoulder the added responsibility.

- Initially the area of operation of RRB to be in one district but a flexible appraoch to be adopted in determining the area of operation of RRB.

- $60 \%$ of loans and advances of RRBs to be earmarked for the benefit of small farmers, rural artisans and rural poor.

- Operational aspects of RRBs to be looked after by RBI instead of Central Govt. (NABARD was not in existence by that time)

- Share Capital may be contributed by RBI (25\%), Sponsor Bank(40\%), State Govt (25\%) and local bodies (20\%)

- Board to have district developmental officials, persons with local knowledge, bank officials so as to have a proper mix of technical, banking and local needs / aspirations.

- Chairman to be appointed by the Board of RRB with concurrence of RBI.

- RBI relaxations / concessions may be retained for first 05 years of its existence.

- A separate institution for training needs of RRBs may be set up by sponsor banks. 
Committee to Review Arrangements for Institutional Credit for Agriculture and Rural Development (CRAFICARD, 1981)

- The balance of advantage lies in encouraging commercial banks to transfer the eligible business of their rural branches to RRBs wherever possible. RBI should facilitate such transfer as and when such proposals were made.

- The losses incurred by a RRB should be made good annually by the shareholders in the same proportion of their shareholdings.

- In areas where the terrain is difficult, the accessibility is limited, the area itself requires further monetisation and particularly all families belonging to weaker sections as in North Eastern Regional (NER), the approach to RRB may have to be different and it may be allowed to cover larger areas and also finance all the categories of borrowers for all purpose.

- The recommendations of the Dantwala Committee for transfer of entire control, regulation as well as the promotional and developmental responsibilities relating to RRBs from GOI to the RBI, was endorsed and recommended with the modificaton that NABARD would take the place of the RBI in the new step.

Working Group on Regional Rural Banks (Kelkar Committee, 1984)

- RRBs be allowed to provide credit to select institutions such as SC/ST corporations, local bodies, housing boards etc. besides the target group. Such loans should be given only to financially sound institutions and for productive purposes alone.

- Small and uneconomic RRBs to be merged in the interest of economic viability.

- Accumulated losses of RRBs to be shared by the shareholders in the form of grants to RRBs in proportion to their equity holding.

- For meeting their SLR requirements, RRBs should invest in Govt. securities with support from sponsor bank.

\section{Agricultural Credit Review Committee (ACRC, 1989)}

- The Committee took note of the serious organisational problems of RRBs on account of the continuous decline in profitability, poor recoveries and problems relating to management and staff.

- The Committee noted that major factor which contributed to the erosion of RRBs' margins and high operating costs involved in handling of small loans. They did not have any scope of cross subsidization in the absence of loans that could yield higher returns. Wilful defaults, misuse of loans, lack of follow-up, wrong identification of borrowers, extension of denami loans, staff agitations etc. also led to poor recoveries 
in RRBs, noted the Committee.

- The objective of serving the weaker sections effectively could be achieved only by self-sustaining credit institutions. RRBs' structurally are not the institutions thatr could fulfill this role. The Committee noted that the logical and rationale which justified the setting up of RRBs did no longer exist. The weaknesses of the RRBs are endemic to the system and non-viability is built into it.

- The Committee also explored the possibilities of improving enlargement of the share capital, provision of bad debt reserve, providing large access to more resilient customers and even giving them a subsidiary status to the commercial banks. However, these alternatives were found to be unsatisfactory as, in the opinion of the Committee, the RRBs did not solve problems of effective service to the rural poor.

- The Committee thought it proper that the only feasible alternative would be to merge the RRB-structure and the branches with the concerned sponsor banks by making necessary amendments to the existing laws.

Committee on Financial System (Narasimham Committee, 1991)

- The problem of the RRBs is one of improving their viability without scarificing the basic objective for which they were set up.

- To impart viability to the operations of RRBs, they should be permitted to engage in all type of banking business and should not be forced to restrict their operations to the target groups.

- To improve their viability further, a mechanism be worked out under which the RRBs should be able to place their surplus funds with NABARD or with a special agency that might be set up for the purpose which should pay interest on such balances by investing or deploying these funds to the best advantage on behalf of RRBs.

- The solution lies in evolving a rural banking structure which would combine effectively the advantage of the local character of the RRBs and the strength and the organizational and managerial skills of commercial banks. The need is to establish a viable banking structure which could effectively meet rural credit needs. The Committee recommended that each public sector bank should set up one or more rural banking subsidiaries to take upon its all rural branches. It was left on the RRBs and their sponsor banks as to whether the RRBs should retain their separate identity or they should be merged with such rural subsidiaries.

\section{Committee on Restructuring of RRBs (Bhandari Committee, 1994)}

- Apart from identifying $49 \mathrm{RRBs}$ for comprehensive restructuring, the committee 
92 |MUDRA: Journal of Finance and Accounting, Volume 3, Issue 2

made wide ranging recommendations relating, inter-alia, to the appointment of Chairman / CEO, delineation of roles and responsibilities of supervising agencies of RRBs, staff matters, improving returns on SLR and non-SLR investments and improving funds management, augmentation of share capital, expansion of the scope of business avenues, deregulation of interest and rationalization of branch licensing policy.

- Special emphasis was laid on skills up-gradation of the staff of RRBs.

- Professionals and not the politicians be nominated on the Boards of RRBs.

- Greater devolution of decision making powers to the Boards of RRBs in the matters of business development and staff matters.

Working Group on Funds Management in RRBs (Misra Committee, 1995)

- A graduated investment by RRBs in Govt. securities.

- Introduction of special deposit scheme of 15 days' maturity period for SLR investments of RRBs with sponsor banks with interest rate on such deposits being pegged at $0.50 \%$ less than the coupon rate on dated GOI securities as on date of such investments.

- Widening the scope for non-SLR investments of RRBs.

- Strengthening the Operational set up for Investment Management in RRBs.

- Pooling of surplus funds of all RRBs for investment through an asset-management group and a national center for exchange of information that could be managed by NABARD.

- Introduction of Guarantee Bond System for management of cash till consideration of currency chests in RRBs.

- General exemption to RRBs from Income Tax on the income from investment of their rural deposits.

Committee on Revamping of RRBs (Basu Committee, 1996)

- Apart from identifying 68 RRBs for restructuring under Second Phase, Basu Committee made certain recommendations on operational matters as well.

- Introduction of Prudential Norms for RRBs with suitable modifications.

- Subsidising RRBs to the extent of the cost of DICCGCI premium in respect of loans below Rs.25000/- or allowing RRBs to pass on this cost to the borrower.

- Introduction of a Floating Rate Mechanism linked to the coupon rates for improving yields on SLR investments of RRBs.

- Need to redefine the role of shareholders of RRBs more precisely. 
- Broad-basing the selection of Chairman of RRBs.

- Some of the RRBs might not be able to respond positively to the 'Stand Alone' Approach or any other revamping strategy; liquidation of such RRBs might be the only solution.

Expert Group on RRBs (Thingalaya Committee, 1997)

- Categorisation of RRBs as per their viability status and size to provide appropriate policy treatment to them.

- Very weak RRBs to be viewed separately and possibility of their liquidation be recognized. They might be merged with neighbouring RRBs.

- Special package for RRBs in North-Eastern Sector.

- RRBs to be permitted to open branches at centres having high business potential.

- Adequate autonomy to Board of Directors for decisions on all matters relting to business without having to refer to apex authorities.

- Delegation of authorities as per the size and viability status of RRBs.

- Strengthening of Internal Inspection System and set-up in RRBs and introduction of Vigilance Cells.

- Realistic RRB - specific staff review and recruitment policy.

- Role overlap between RBI, NABARD and Sponsor Banks to be avoided.

\section{Committee on Banking Sector Reforms (Narasimham Committee, 1998)}

- Banking system should be in a position to build a credit culture and discipline by equipping itself to identify the eligible clients, based on the prescribed norms, in the government sponsored schemes so that full responsibility for all aspects of credit decision remains with it. This would also help improve the client-bank relationship instead of the present system of virtually imposed clientele.

- RRBs should reach a minimum of $8 \%$ of capital to risk weighted assets over a period of 5 years. A review of a capital structure of the RRBs should be undertakn with a view to enlarging public subscriptions and the sponsor banks be given greater ownership and responsibility in the operation of RRBs.

- The supervisory functions over rural financial institutions have been entrusted to NABARD. While this arrangement may continue for the present, over the longer term the Committee suggested that all regulatory and supervisory functions over rural credit institutions should vest with the Board for Financial Regulation and Supervision.

- Banking policy should facilitate the evolution and growth of micro-credit institutions 
including LABs which focus on agriculture, tiny and small scale industries, including such specialist institutions as may be promoted by NGOs for meeting the banking needs of the poor.

- NABARD to prepare a checklist of various recommendations of the Committees set up in the past on RRBs that remain unimplemented and positive steps be taken to bring the RRBs on the right path of efficiency, solvency, productivity and profitability without undermining the ultimate objectives of rural development.

- RRBs must rationalize and amend their loan policies and procedures so as to function as a development banker for the rural poor.

- RRBs must work in close coordination with the cooperative banks and rural branches of commercial banks to fill the credit gap in rural areas without any clash of mutual interests.

- While discharging their functions as purveyors of rural credit and mobilisers of rural savings, RRBs should not ignore the importance of financial viability and operational efficiency. The productivity, profitability and solvency of the RRBs must be maintained and sustained to enable them to function as an effective and efficient institution of rural credit.

Committee on Manpower Norms in RRBs (Agrawal Committee, 2000)

- Norms for staffing in RRBs be pegged at 4.20 per unit (HO/ Area Office / Branch being treated as one unit each), with relaxation for RRBs in North-Eastern Region and hilly and desert areas. Additional manpower to be available only for RRBs with CD Ratio exceeding 60\% and NPAs lower than the industry average by $5 \%$ points.

- Staffing set-up of head office of RRBs has been suggested in four categories separately for RRBs with branches upto 50, those upto 100 branches, those with upto 150 branches and those having more than 150 branches.

- Area Offices for every 25 branches with its location in the field.

- One scale up-gradation of the posts of Chairman, General Manager and Area Managers / Senior Managers.

- Manpower surplus / shortages to be managed by deputation of staff from surplus RRBs to deficit RRBs, by opening new branches / closure of unviable branches, computerization, outsourcing, redeployment of staff etc.

- RRB-staff with due experience to be considered for the post of General Manager.

- Abolition of clerical cadre over a period of time by converting the staff into multipurpose workers.

- RRBs to achieve computerisation in Head Office,Area Office and at least 50\% of its 
branches in 5 years period.

\section{Expert Committee on Rural Credit (ECRC, 2001)}

- To find out some other willing party (sponsor banks, RRB Employees themselves or some non-banking financial companies) to take over the share of defaulting State Governments (along-with the right of nomination to the Board) at a fair price determined independently by a professional.

- The GOI to review its system of nominating non-official directors and nominate non-official directors from a panel of professionals recommended by NABARD, sponsor bank or even the RRB itself.

- Sponsor banks to review their own systems of support and monitoring of RRBs' performance and ensure that necessary autonomy in innovation of credit products as also credit and other portfolio management ystems are ensured for RRBs.

- GOI to recognise RRBs which do not carry forward any accumulated losses as Local Area Banks (LABs), convert them into banking companies and incorporate them as such in the Companies Act. They need strong, regionally oriented management and larger capital flow. For this purpose, strategic local partners in the private sector may be needed. Employeed of concerned banks may also be conisdered as a strategic partner. Such banks may also be allowed to access capital markets for initial public offerings of their shares particularly to meet capital adequacy requirements.

- No new LABs other than those converted from RRBs or sponsored by nongovernment or voluntary agencies need be set up in the private sector in future. We have to recognise that RRBs are already LABs in the public sector.

- As far as possible, sponsor banks' nominees on RRB boards should be from their Zonal or Head Offices, a little away from the area of operation of the RRB and help correct perceptions of RRB personnel regarding pressure from local controlling offices of the sponsor banks for various purposes.

- Sponsor banks are often not prompt in handling references from RRBs. Some of these remain pending with bodies such as NABARD, RBI or GOI. Sponsor Banks should accord urgency to such references to help RRBs find early solutions to their problems.

Advisory Committee on Flow of Credit to Agriculture and Related Activities (Dr.Vyas Committee, 2004)

- Mandate of RRBs has to continue, even as they need to be restructured into viable financial institutions, while retaining their regional character and rural tours. 
- All RRBs in the North Eastern States be merged into a Zonal bank on stand alone basis, the equity of which is to be provided by NABARD, SBI and UBI in the ratio of 26:37:37 through a holding company. They newly constituted bank will function independently with CEO and a BOD and will be delinked from the sponsor banks.

- A two-step amalgamation of RRBs for the rest of the country, under first step, all RRBs of a sponsor bank in a state would be amalgamated into a single unit. Sponsor bank and NABARD will contribute to the equity of the RRB through a holding company in the ratio of 26:74. Under 2 nd phase, state level rural bank will be formed by amalgamating all RRBs (amalgamated and stand alone). Thus 20 state level rural bank will emerge after 2nd phase.

- The State / Zonal RRBs may be permitted to seek cheaper funds through issue of certificate of deposits.

- Income tax exemptions granted to RRBs be continued to be newly formed State / Zonal RRBs.

- RRBs Act, 1976 may be repeated and replaced by a new Act with suitable provisions for functional autonomy to the restructured RRBs and professionalized of management and Board of Directors

\section{Committee on Recapitalisation of RRBs (Chakrabarty Committee 2011)}

- The Committee carried out an assessment of capital requirement for all 82 RRBs to enable them to have CRAR of at least 7\% as on March 31, 2011 and at least 9\% from March 31, 2012 onward. The recapitalisation requirement would be Rs. 2200 crore for 40 out of 82 RRBs. This amount may be released in two instalments i.e., Rs. 1338 crore in 2010-11 and Rs. 863 crore 2011-12. The remaining 42 RRBs will not acquire any capital and will be able to maintain CRR of at least $9 \%$ as on March 31, 2012 and thereafter on their own.

- The committee noted that some of the weak RRBs, particularly in North-Eastern and Eastern regions, might not be able to fully meet all the projected business parameters despite generally achieving acceptable growth. The committee, therefore suggest that an additional amount of Rs. 700 crore may be kept to meet such contingencies and need based additional capitalisation provided to such RRBs once their draft balance sheets are prepared.

- The recapitalisation of Rs. 2200 crore to 40 RRBs should be one time measure, and released subject to signing of memorandum of understanding (MoU) by the chairman of the RRB and on achieving the performance parameters specified in MoU. As per section 5 of the RRB Act, the authorized capital of RRB is Rs. 5 Crore. 
As a result recapitalisation amount are kept as share capital deposit. The committee has recommended that the accumulated losses on March 31, 2010 may be written off against the available share capital deposits and the balance amount of share capital deposit may be appropriated as paid-up capital further, in view of expanding business of the RRB, the committee recommended to increase in the authorized capital RRBs to Rs. 500 crore.

- In order to build public confidence, in due course, RRB with higher net worth may be allowed to access capital from the market.

- For improving the functioning of the RRB, change of sponsor banks may be considered, where ever required.

- RRB with a net worth of Rs. 100 crore or more as on March 2009 may be permitted to pay dividend on April 1, 2013 onward. RRBs to be recapitalised in the current phase may be allowed to pay dividend only after achieving a sustainable CRAR of at least $9 \%$.

- RBI may prescribe "Fit and Proper" criteria for chairman of RRB. The sponsor may depute officer conforming to such criteria as Chairman on a tenure basis and wherever needed, such officers may be recruited by them from open market and the deputed to RRBs. The compensation of chairman may be de-linked from existing salary structure of commercial banks and be more market oriented and a system of incentives and disincentives linked to performance benchmarks approved by the board may be built in the compensation package.

- The board as a body as well as individual board members may be made accountable for the banks performance and individual board need to be assigned specific responsibilities as per their expertise.

- Wherever required, sponsor banks may recruit suitable person from the market, including staff of the RRB in their own service and then depute them as general managers in RRBs.

\section{Annexure II: The Regional Rural Banks (Amendment) Bill 2014: Summary}

- The Regional Rural Banks (Amendment) Bill, 2014 was introduced by the Minister of Finance, Mr. Arun Jaitley, in Lok Sabha on December 18, 2014. The Bill seeks to amend the Regional Rural Banks Act, 1976.

- The Regional Rural Banks Act, 2014 mainly provides for the incorporation, regulation and winding up of Regional Rural Banks (RRBs). 
- Sponsor banks: The Act provides for RRBs to be sponsored by banks. These sponsor banks are required to (i) subscribe to the share capital of RRBs, (ii) train their personnel, and (iii) provide managerial and financial assistance for the first five years. The Bill removes the five year limit, thus allowing such assistance to continue beyond this duration.

- Authorised capital: The Act provides for the authorised capital of each RRB to be Rs five crore. It does not permit the authorised capital to be reduced below Rs 25 lakh. The Bill seeks to raise the amount of authorised capital to Rs 2,000 crore and states that it cannot be reduced below Rs one crore.

- Issued capital: The Act allows the central government to specify the capital issued by a RRB, between Rs 25 lakh and Rs one crore. The Bill requires that the capital issued should be at least Rs one crore.

- Shareholding: The Act mandates that of the capital issued by a RRB, $50 \%$ shall be held by the central government, $15 \%$ by the concerned state government and $35 \%$ by the sponsor bank. The Bill allows RRBs to raise their capital from sources other than the central and state governments, and sponsor banks. In such a case, the combined shareholding of the central government and the sponsor bank cannot be less than $51 \%$. Additionally, if the shareholding of the state government in the RRB is reduced below $15 \%$, the central government would have to consult the concerned state government.

- The Bill states that the central government may by notification raise or reduce the limit of shareholding of the central government, state government or the sponsor bank in the RRB. In doing so, the central government may consult the state government and the sponsor bank. The central government is required to consult the concerned state government when reducing the limit of shareholding of the state government in the RRB.

- Board of directors: The Act specifies the composition of the Board of Directors of the RRB to include a Chairman and directors to be appointed through the central government, NABARD, sponsor bank, Reserve Bank of India, etc. The Bill states that any person who is a director of an RRB is not eligible to be on the Board of Directors of another RRB.

- The Bill also adds a provision for directors to be elected by shareholders based on the total amount of equity share capital issued to such shareholders. If the equity share capital issued to shareholders is $10 \%$ or less, one director shall be elected by such shareholders. Two directors shall be elected by shareholders where the equity share capital issued to them is from $10 \%$ to $25 \%$. Three directors shall be elected in 
case of equity share capital issued being $25 \%$ or above. If required, the central government can also appoint an officer to the board of directors to ensure effective functioning of the RRB.

- The Act specifies the term of office of a director (excluding the Chairman) to be not more than two years. The Bill raises this tenure to three years. The Bill also states that no director can hold office for a total period exceeding six years.

- Closure and balancing of books: As per the Act, the books of a RRB should be closed and balanced as on December 31 every year. The Bill changes this date to March 31 to bring the Act in uniformity with the financial year.

The Bill was introduced on December 18, 2014 and subsequently passed by the Lok Sabha on December 22, 2014 and the Rajya Sabha on April 28, 2015. 